石油技術協会誌 第 75 巻 第 6 号（平成 22 年 11 月） 452 ～ 461 頁

Journal of the Japanese Association for Petroleum Technology

Vol. 75, No. 6 (Nov., 2010) pp. 452 461

\title{
講演 \\ Lecture \\ An integrated approach combining tracer injection/monitoring and other surveillance application for reservoir management in Rang Dong basement reservoir ${ }^{*}$
}

\author{
Ooi Kiam Chai* ${ }^{* *}$ Atsushi Hatakeyama ${ }^{* *}$ and Nguyen Chu Chuyen ${ }^{* *}$
}

(Received September 9, 2010 ; accepted November 2, 2010)

\begin{abstract}
Rang Dong basement reservoir is a granitic naturally fractured reservoir. Unlike carbonate fractured system, basement matrix porosity is negligible. The storage and production are dominated by the fracture system. After primary depletion, water injection was commenced to further improve the oil recovery and production of the reservoir. Water injection in fractured reservoir is particularly challenging as it is very much dependant on the fracture connectivity, geometry and orientation. To manage the water injection strategy of the basement reservoir, a thorough understanding of the fluid flow is crucial. Therefore, radioactive tracer injection/monitoring were employed in different part of the field to obtain information on fluid path.

Tracer injection/monitoring have been established as a proven and efficient technology to obtain information on wellto-well communication, heterogeneities and fluid dynamics. However, interpretation may in some cases not straight forward, therefore integration with other types of reservoir and production data are important to get a consistent and accurate interpretation.

This paper demonstrates an integrated approach where it combined tracer injection/monitoring with other surveillance application for well planning and reservoir management. One of the surveillance is the monitoring of the water chemical composition through regular sampling and analysis of produced water. This method serves as the tracking of movement of formation/aquifer water and injected seawater. Another analysis involves the monitoring of produced water isotopes. Oil finger printing is also used as another source of information to be combined into the overall interpretation. Oil finger printing is used to identify any reservoir compartmentalization, reservoir extent and connectivity. Other reservoir data and applications used are well production performance, well pressure transient analyses, material balance analyses and etc.

This paper documents some actual examples where the tracer injection/monitoring analyses integrated with all available information were used to derive at actual well planning or reservoir management strategy that was eventually applied in the field.
\end{abstract}

Keywords : Tracer injection/monitoring, naturally fractured reservoir, basement reservoir, integrated approach to reservoir management

\section{Introduction}

Rang Dong field is part of the Block AA located in the offshore of southern Vietnam, $160 \mathrm{~km}$ from the block boundaries off Vung Tau at the mouth of Mekong River (Fig. 1). The Block AA is geologically located in the central and northeastern part of the Mekong Basin, in which thick Tertiary sediments are deposited.

The Rang Dong field is NE-SW trending basement high which is composed of Cretaceous igneous rocks such as granite and granodiorite and lies in the same structural trend with the Bach Ho field to the south west and the Phuong Dong field to

*平成 22 年 6 月 10 日, 平成 22 年度石油技術協会春季講演会開発・生産シ ンポジウム「坑井モニタリング技術とデータ活用法」で講演 This Paper was presented at the 2010 JAPT Development and Production Technology Symposium entitled "Well surveillance and data interpretation for reservoir management" held in Fukuoka, Japan, June 10, 2010.

** Japan Vietnam Petroleum Company, Ltd (JX Group)

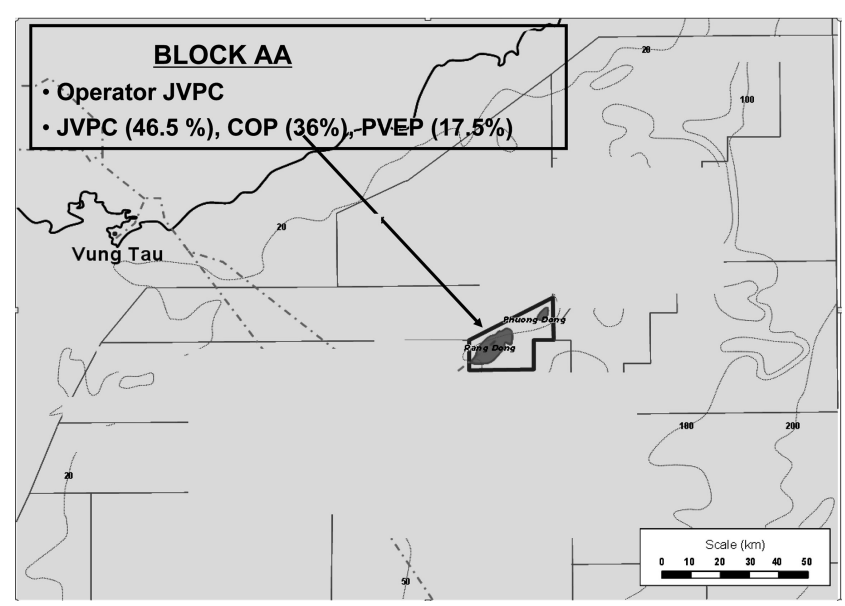

Fig. 1 Rang Dong Field Location Map 


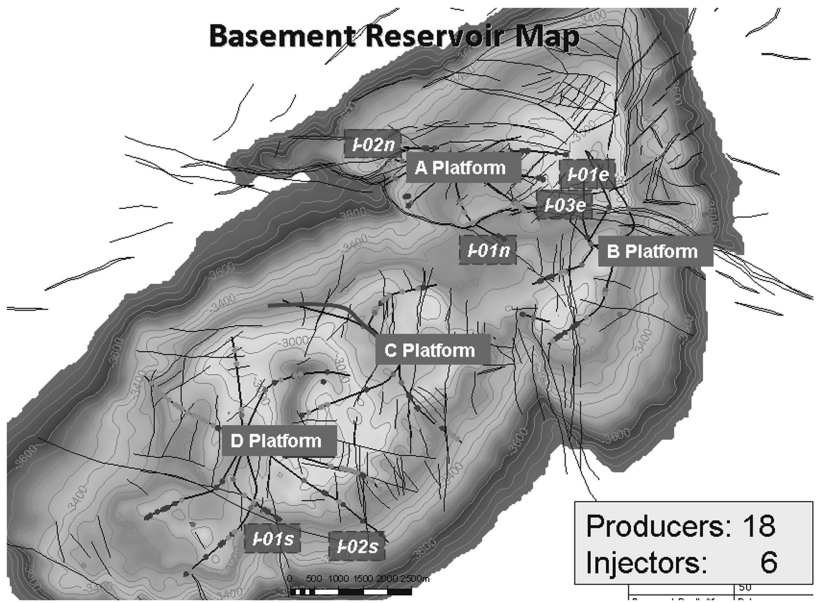

Fig. 2 Basement Reservoir Map with Water Injector Locations

the northeast. The Rang Dong basement is the largest structure in the Block AA. Oil accumulation was confirmed in granitic basement and Lower Miocene sandstone by the first exploratory well in 1994 and following appraisal wells.

In 1998, Japan Vietnam Petroleum Company Ltd (JVPC) as operator of Block AA achieved 1st oil from Rang Dong Basement Reservoir. ConocoPhillips and PetroVietnam Exploration Production Corporation (PVEP) are partners of this block. Rang Dong Basement Reservoir have 18 oil producers and 6 injectors (Fig. 2). Rang Dong basement reservoir is a granitic naturally fractured reservoir. It belongs to TYPE-1 of fractured reservoir $\left(\right.$ Nelson $^{1)}$ ) where fractures provide the all essential storage capacity and permeability, the matrix has little or no porosity and permeability.

Reservoir pressure declined below bubble point pressure $(\mathrm{Pb})$ soon after production started with $\mathrm{Pb}$ only 600 psi lower than initial reservoir pressure. Secondary gas cap resulted as free gas due to pressure depleted below $\mathrm{Pb}$. The formation of the secondary gas cap has lead to gas cap drive adding to oil expansion and rock compressibility as the primary reservoir drive mechanism at that time. Clear GOR increase was observed in some wells as evident of secondary gas cap. Some aquifer support were seen however they are limited strength and clearly not enough to sustain the reservoir pressure. In February 2004, water injection was commenced to further improve the oil recovery and production of the reservoir. Shortly after that, radioactive tracer injection project was started. Wells in the basement are mostly highly deviated to horizontal wells designed to penetrate multiple fractures for maximum productivity and recovery. Therefore, there exists very heterogeneous connectivity and communication between wells. In general, most wells are producing high water cut and high GOR.

\section{Tracer Application Motivation and Objective}

Water injection in fractured reservoir is particularly challenging as it is very much dependant on the fracture connectivity, geometry and orientation. To manage the water injection strategy of the basement reservoir, a thorough understanding of the fluid flow is crucial. Therefore, inter-well tracer injection/monitoring was employed in different part of the field to answer some of the uncertainties in water flooding in fractured reservoir. The uncertainties are on the movement of water injection, the injector-producer connectivity (i.e. direct, indirect or isolated connection), the swept volume and time of injected water to arrive at producer (s). The methodology applied is using a slug inter-well tracer injection starting from the injector ( $\mathrm{s}$ ) and then monitor the tracer breakthrough time, tracer residence time and tracer concentration versus time at the producer (s). The tracer injection / production volume response and shape will be then evaluated to figure out the number of flooded conduits and swept volume from injector to producer.

Tracer testing in the petroleum industry started in 1962 and is a well-established technique to evaluate inter-well communication as well as reservoir heterogeneity (Greenkorn ${ }^{2)}$, Wagner $^{3)}$, Zemel $^{4)}$, Shook ${ }^{5)}$ ).

\section{Injected Tracers Summary and Background}

Four (4) types of radioactive tracers were injected as tracer pulse at constant injection rate. All the injected tracers are water soluble and are stable in reservoir condition. The injected tracers are summarized as below.

- HTO (Tritiated water) - This is beta tracer tagged with radioisotope tritium $(\mathrm{H}-3)$

- $\mathrm{MtOH}$ (Methonol) - This is alcohol tracer tagged with $\mathrm{C}-14$ beta isotopes

- EtOH (Ethanol) - This is alcohol tracer tagged with radioisotope tritium $(\mathrm{H}-3)$

- BZA (Benzoic Acid) - This is acid tracer tagged with C-14 beta isotopes

Table 1 summarized the characteristic and details of all tracers used. The individual tracer was injected directly into the flow line of injection near the water injector wellhead. Fig. 3 illustrates the tracer injection point near the wellhead in a schematic. On the other end, water samples were collected regularly at the well head of the oil producers with a sampling devise. Fig. 4 showed the sampling point where the water was collected.

Table 1 Summary Table of the 4 Tracers Used for each Water Injector

\begin{tabular}{|c|c|c|c|c|c|c|}
\hline \multirow[t]{2}{*}{ Well } & \multirow[t]{2}{*}{ Tracer type } & \multirow{2}{*}{$\begin{array}{c}* \mathrm{MDL} \\
(\mathrm{Bq} / \mathrm{l})\end{array}$} & \multicolumn{2}{|c|}{ Injected Tracer Vol. } & \multirow{2}{*}{$\begin{array}{c}\begin{array}{c}\text { Inj } \\
\text { Time }\end{array} \\
\text { hrs } \\
\end{array}$} & \multirow{2}{*}{$\begin{array}{c}\text { Inj } \\
\text { Rate } \\
\text { b/d } \\
\end{array}$} \\
\hline & & & $\mathrm{Ci}$ & $\mathrm{Bq}$ & & \\
\hline 1-01s & HTO & 23.15 & 300.00 & $1.11 \mathrm{E}+13$ & 2 & 20,000 \\
\hline $1-02 n$ & HTO & 23.15 & 360.00 & $1.33 \mathrm{E}+13$ & 2 & 20,000 \\
\hline $1-02 \mathrm{~s}$ & $\mathrm{EtOH}(\mathrm{H}-3)$ & 0.24 & 1.50 & $5.55 \mathrm{E}+10$ & 2 & 1,000 \\
\hline $1-01 \mathrm{e}$ & $\mathrm{EtOH}(\mathrm{H}-3)$ & 0.24 & 3.30 & $1.22 \mathrm{E}+11$ & 2 & 6,500 \\
\hline $1-01 n$ & $\mathrm{MeOH}(\mathrm{C}-14)$ & 0.13 & 1.10 & $4.07 \mathrm{E}+10$ & 2 & 1,500 \\
\hline $1-03 \mathrm{e}$ & BZA (C-14) & 1.10 & 1.40 & $5.18 \mathrm{E}+10$ & 2 & 7,500 \\
\hline
\end{tabular}

*Minimum Detection Level 


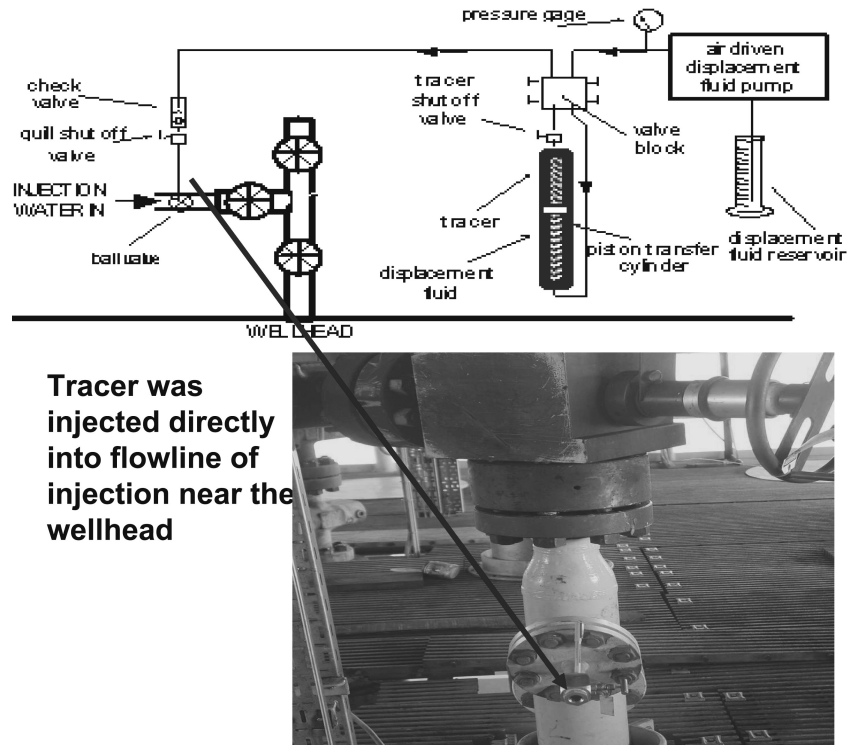

Fig. 3 Tracer Injection Point at the Water Injectors

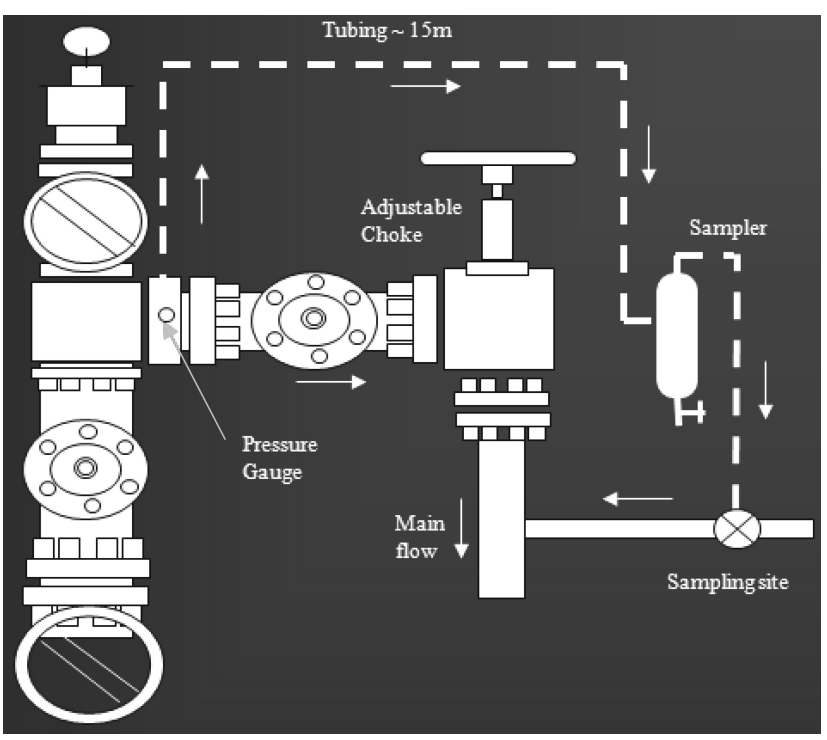

Fig. 4 Tracer Sampling Point at the Well Head of Oil Producers

\section{Tracers Response Results and Other Surveillance Application Interpretation}

Tracer breakthrough was confirmed in the nearby producers and the breakthrough time can be grouped into two groups. 1st group is the early tracer breakthrough oil producers where tracer response can be confirmed very early after tracer injection. Figure 5 shows those injector-producers pairing with solid arrow connection, where early breakthrough was observed in the producers. The 2nd group is where the tracer breakthrough takes longer as a result of indirect communication between injector and producer. Those can be identified in Fig. 5 with dotted line arrows. Table 2 summarizes the breakthrough or arrival time of the tracer for each injector -producer pair. Table 2 also listed the distance between each injector-producer pairing for comparison. The ratios of distance over tracer

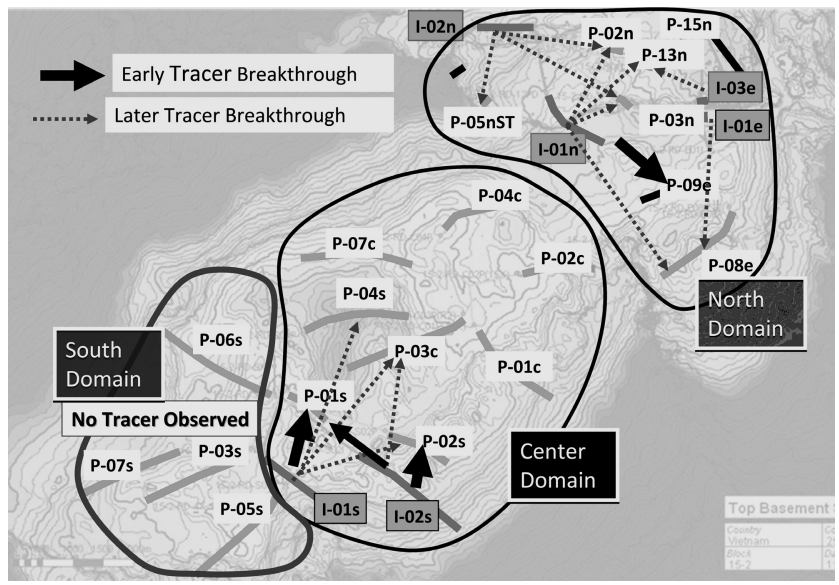

Fig. 5 Tracer Breakthrough Confirmed at each Injector Producer Pairing (Early \& Later BT)

arrival time are also summarized to show that the degree of communication between producer and injector are not just supported by tracer arrival time alone but the effect of distance between the pair of wells are also considered. The injection and production rate are also a determining factor. Ideally, the injection and production rates for all wells are to be kept constant to determine the relative degree of communication. However, due to the differences in injectivity and productivity of each well and some limitation operationally, this was not feasible to be performed.

In the North Domain, clear strong and direct communication can be observed between injector I-01n and P-09e. The tracer arrived in just 96 days and soon after that P-09e producer reached $100 \%$ water cut and high tracer concentration. The tracer response versus time of P-09e can be seen in Fig. 6. This is obvious indication of direct fracture communication between this pair of injector-producer. Only 1 clear tracer concentration peak can be observed, indicating of only a single primary conduit connection. Other supporting data can also be observed. Strong communication between this injector-producer pair can also be seen in the pressure response. Produced water from P-09e also showed clearly that it consisted of injected sea water.

I-01n injector can also be seen to provide water support to producers P-02n, P-03n, P-13n and P-08e in North Domain. The tracers from I-01n arrived at those producers after 500-700 days. The communication was not as direct and strong as compared to P-09e. For example, the tracer injected from I-01n arrived at P-13n only after 683 days. Fig. 7 shows the tracer response versus time of P-13n. The tracer breakthrough at P-13n after water cut reached $50 \%$. P-13n tracer response showed multiple tracer concentration peaks, indication of multiple flooded conduits / fractures.

Other injectors (I-02n, I-01e and I-03e) in the North Domain demonstrated more of an indirect support to nearby wells as shown in Fig. 5. No early tracer breakthrough was observed from these water injectors.

In the Center Domain, clear strong and direct communication can be observed between injector I-01s and P-01s. Tracer from 
Table 2 Tracer Breakthrough/Arrival Timing and Distance for Each Injector-Producer Pairing

\begin{tabular}{|c|c|c|c|c|}
\hline \multicolumn{5}{|c|}{ North Domain } \\
\hline \multirow[b]{2}{*}{ Injector } & \multicolumn{4}{|c|}{ Tracer Response } \\
\hline & Producer & $\begin{array}{c}\text { Arrival } \\
\text { Time (days) } \\
\text { A }\end{array}$ & $\begin{array}{c}\text { Distance } \\
\text { Inj-Prod } \\
(\mathrm{km}) \\
\text { B }\end{array}$ & $\begin{array}{c}\text { Dist. Over } \\
\text { Arrival } \\
\text { Time } \\
\text { (m/day) } \\
\text { B/A }\end{array}$ \\
\hline \multirow{5}{*}{$\begin{array}{c}\text { 1-01n } \\
(\mathrm{MtOH})\end{array}$} & P-02n & 676 & 1.42 & 2.1 \\
\hline & P-03n & 614 & 0.98 & 1.6 \\
\hline & P-13n & 683 & 1.62 & 2.4 \\
\hline & P-08e & 541 & 2.98 & 5.5 \\
\hline & P-09e & 96 & 2.02 & 21.0 \\
\hline \multirow{3}{*}{$\begin{array}{l}1-02 \mathrm{n} \\
\text { (HTO) }\end{array}$} & P-02n & 650 & 1.67 & 2.6 \\
\hline & P-03n & 614 & 2.20 & 3.6 \\
\hline & P-5nST & 241 & 1.26 & 5.2 \\
\hline $\begin{array}{c}1-01 \mathrm{e} \\
(\mathrm{EtOH})\end{array}$ & P-08e & 306 & 2.08 & 6.8 \\
\hline $\begin{array}{c}1-03 e \\
(\mathrm{BZA})\end{array}$ & P-13n & 331 & 1.05 & 3.2 \\
\hline
\end{tabular}

\begin{tabular}{|c|c|c|c|c|}
\hline \multicolumn{1}{|c|}{ Center Domain } & \multicolumn{4}{|c|}{ Tracer Response } \\
\cline { 2 - 5 } Injector & Producer & $\begin{array}{c}\text { Arrival } \\
\text { Time } \\
\text { (days) A }\end{array}$ & $\begin{array}{c}\text { Distance } \\
\text { Inj-Prod } \\
(\mathrm{km}) \mathrm{B}\end{array}$ & $\begin{array}{c}\text { Dist. Over } \\
\text { Arrival } \\
\text { Time } \\
(\mathrm{m} / \text { day }) \\
\mathrm{B} / \mathrm{A}\end{array}$ \\
\hline \multirow{3}{*}{ 1-01s } & P-01s & 36 & 1.27 & 35.4 \\
\cline { 2 - 5 } (HTO) & P-02s & 177 & 2.26 & 12.8 \\
\cline { 2 - 5 } & P-04s & 202 & 2.83 & 14.0 \\
\cline { 2 - 5 } 1-02s & P-03c & 585 & 2.97 & 5.1 \\
\cline { 2 - 5 }$(\mathrm{PtOH})$ & P-01s & 44 & 2.05 & 46.5 \\
\cline { 2 - 5 } & P-02s & 37 & 0.72 & 19.4 \\
\hline
\end{tabular}

: Early tracer BT and

Strong Communication Injector Producer Pairing

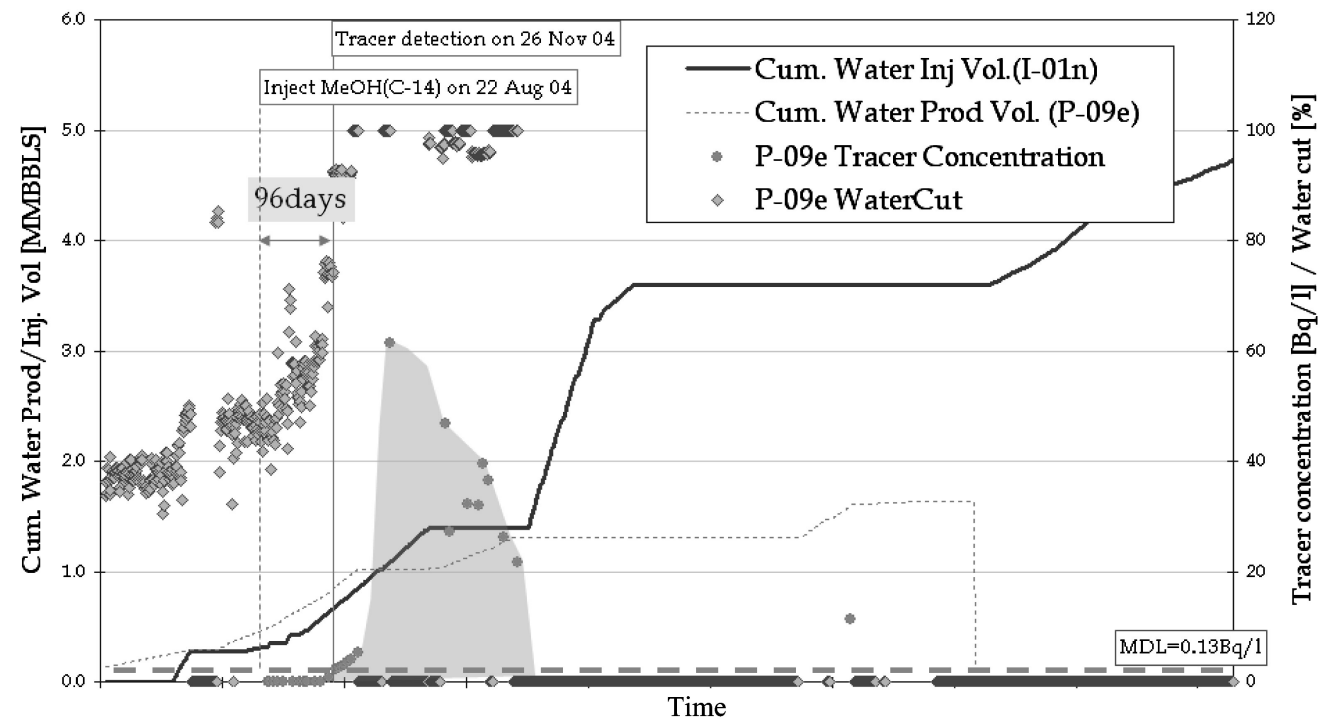

Fig. 6 Tracer Response Curve vs Time for Injector I-01n and Producer P-09e Pairing

I-01s broke through in just 36 days at P-01s (Fig. 8). Tracer breakthrough was seen as soon as the well started producing water. By water injection, strong pressure communication between this pair of well was also clearly observed. Two peaks of tracer concentration were observed very clearly. P-01s has at least two main producing conduits or fractures. I-01s also provided some support to other nearby producers, namely P-02s, P-04s and P-03c.

Another strong communication was also observed from injector I-02s to P-02s and P-01s. Tracer injected from I-02s arrived at P-01s and P-02s in only 44 and 37 days respectively. It was very apparent that I-02s has very strong communication with P-02s, P-02s saw tracer with only very small amount of injected water from I-02s. In addition, very high concentration of tracer was observed at breakthrough with several peaks, as shown in Fig. 9. In order to continue production from P-02s, injection at I-02s had to be shut-in due to rapid water cut increase at P-02s. I-02s tracer also was detected at P-03c.

Comparing between North and Center Domains, there is some differences in terms of tracer breakthrough time. In general, tracer breakthroughs in the Central Domain were shorter than that of North Domain. The understanding is fracture development intensity/density is less in the Center Domain, where fracture lineament is dominated by a single trend. However, on the contrary, in the North Domain multiple fracture lineament trends exist together. This is supported by pressure transient derivative curves (Fig. 10). The pressure response in late time indicates flow behavior similar to that belongs to a dense fracture network reservoir in the North Domain.

In the South Domain, all 4 producers (P-03s, P-05s, P-06s 


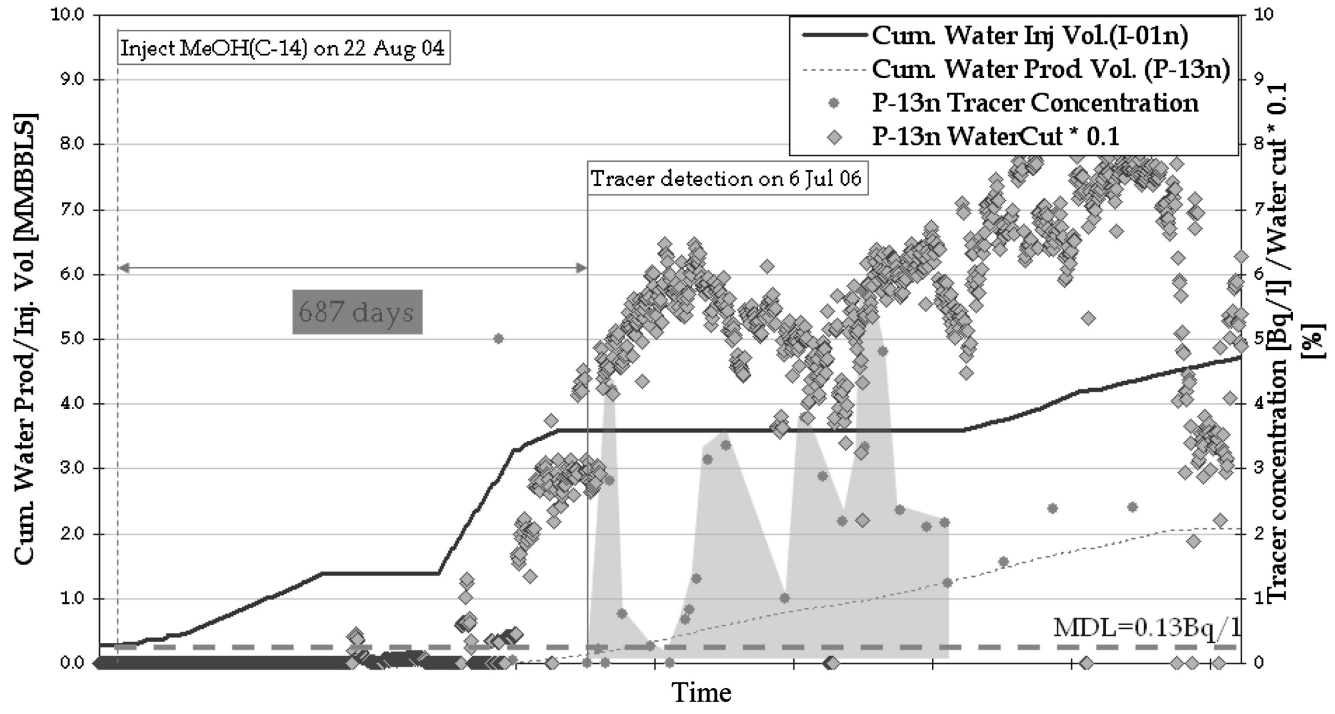

Fig. 7 Tracer Response Curve vs Time for Injector I-01n and Producer P-13n Pairing

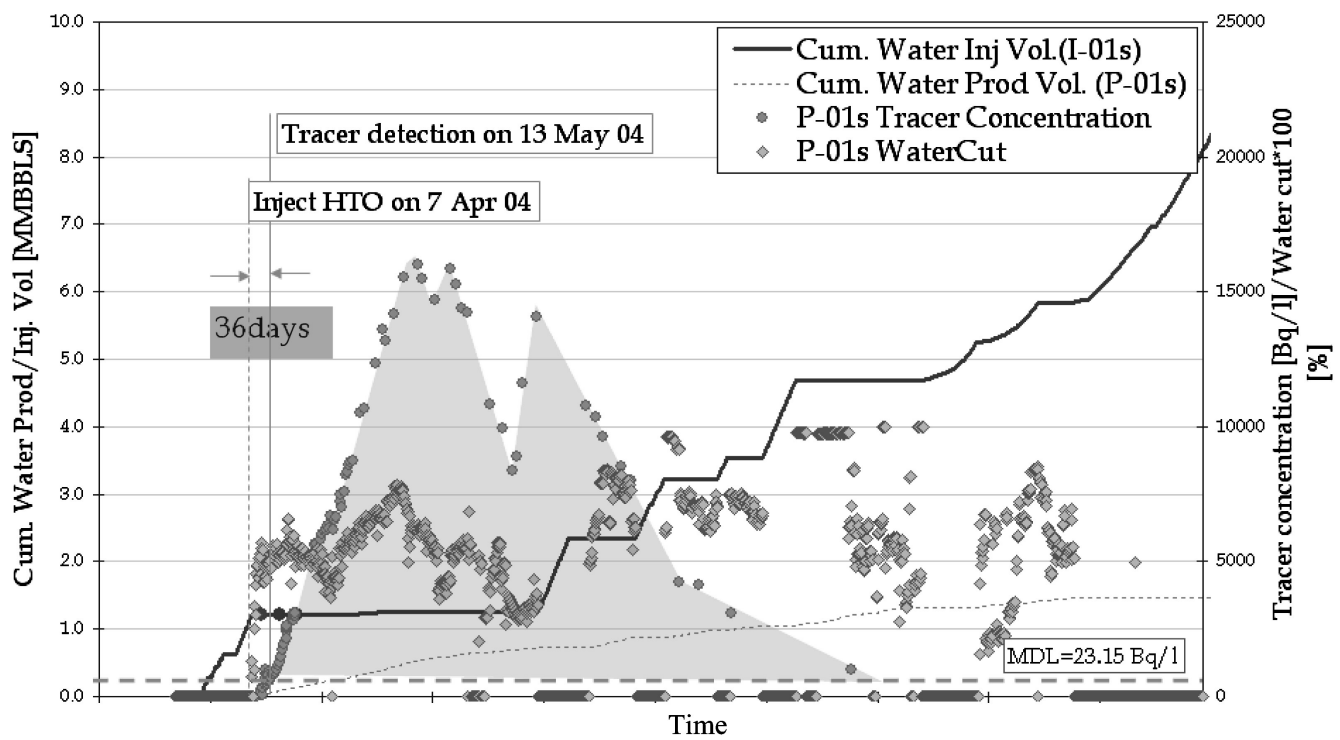

Fig. 8 Tracer Response Curve vs Time for Injector I-01s and Producer P-01s Pairing

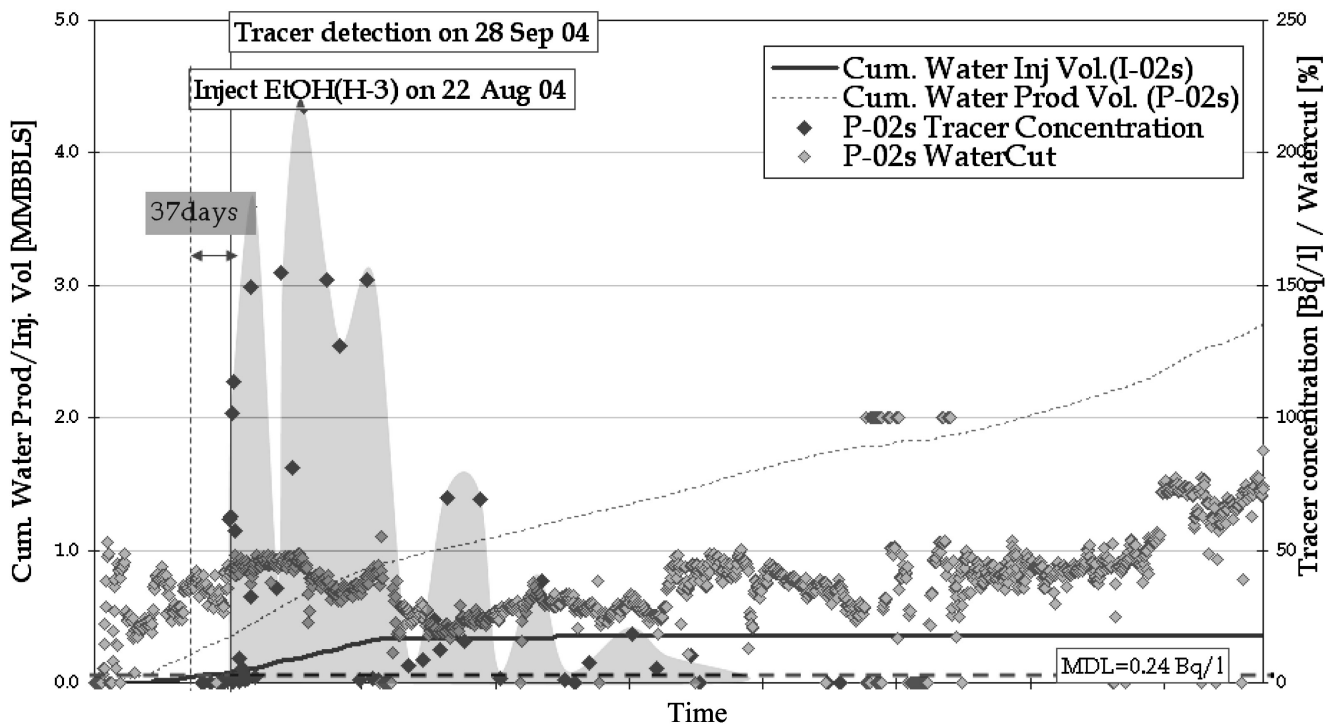

Fig. 9 Tracer Response Curve vs Time for Injector I-02s and Producer P-02s Pairing 


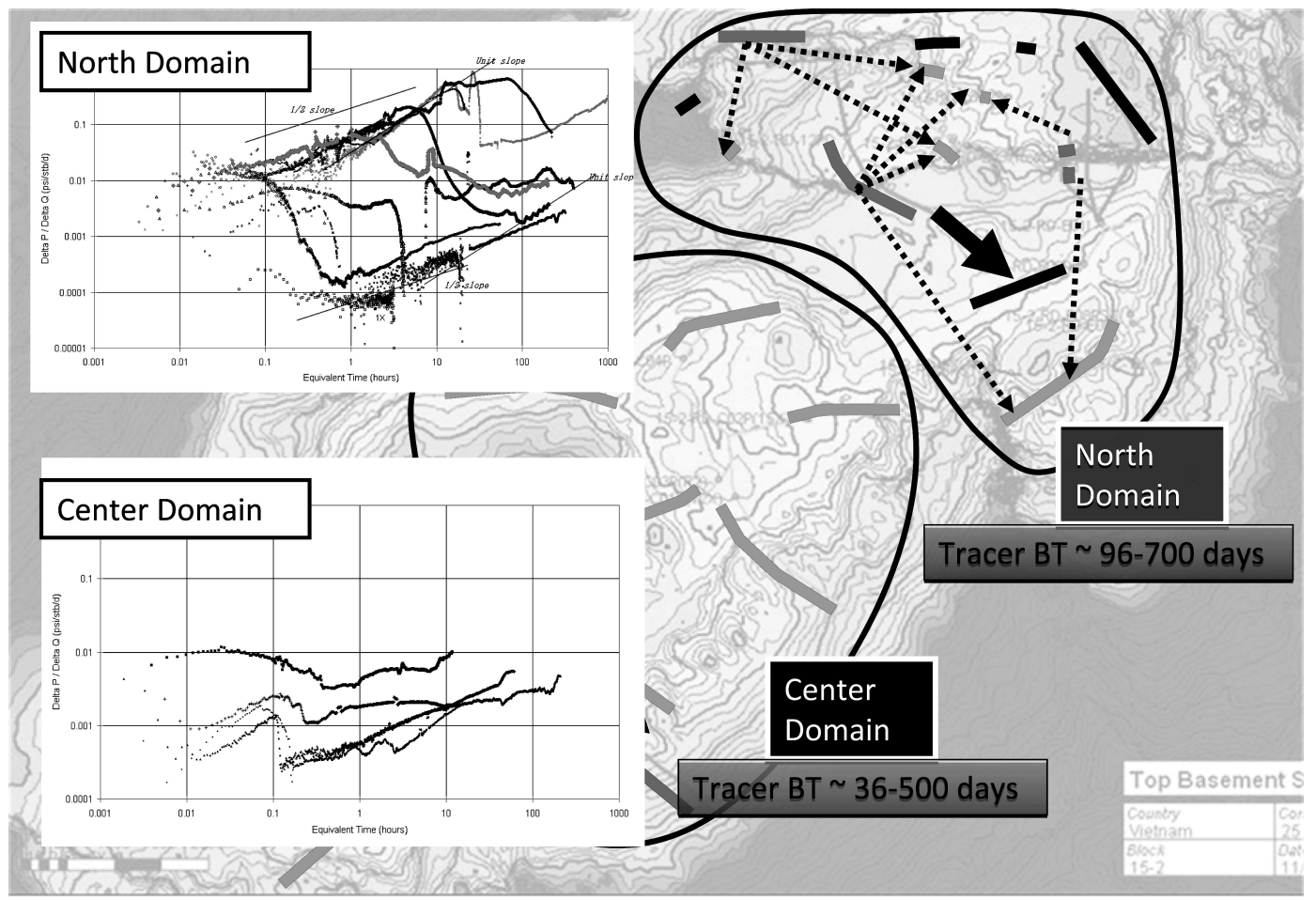

Fig. 10 Pressure Transient Derivative Curve Comparison Between North and Center Domains

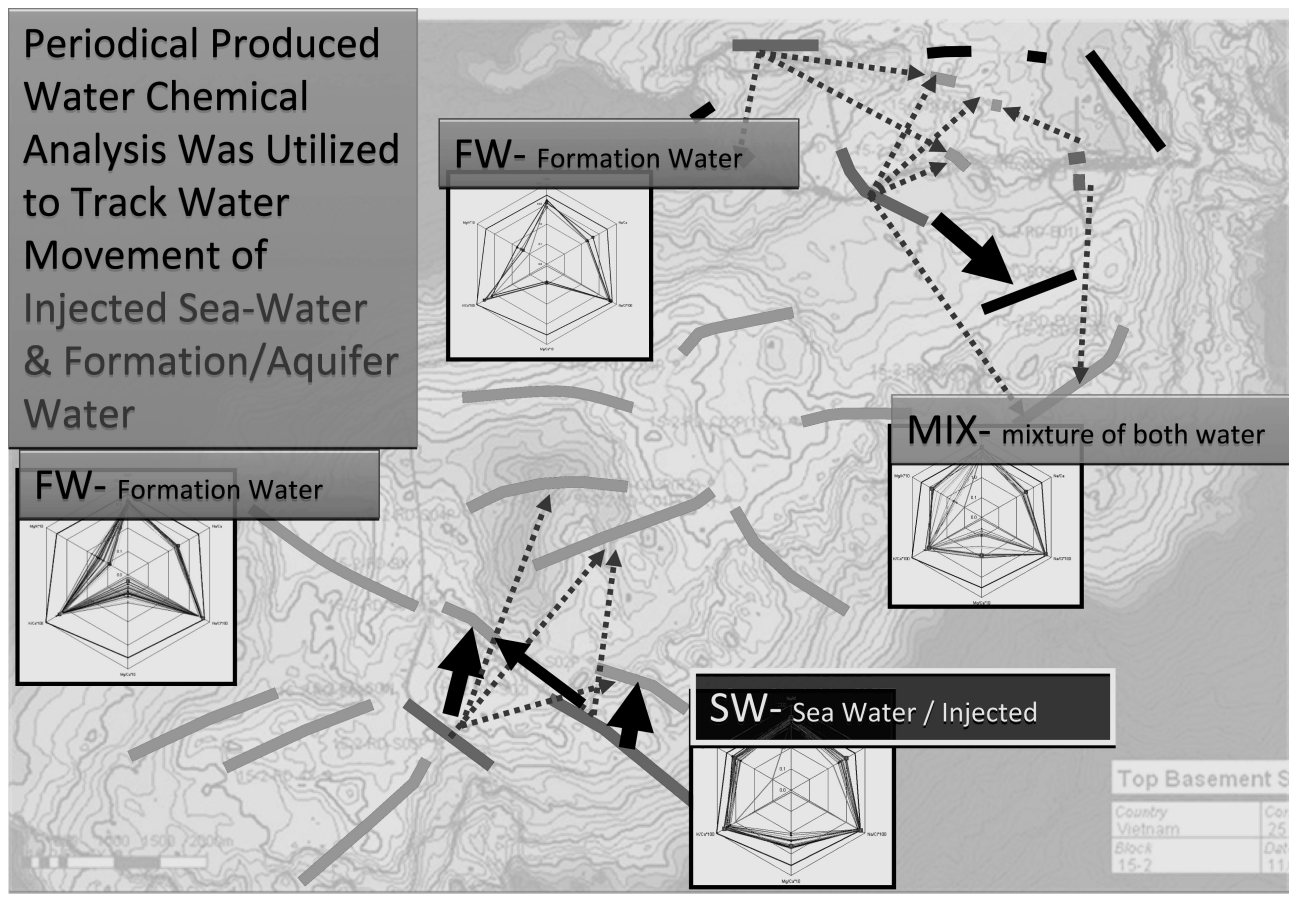

Fig. 11 Produced Water Chemical Analysis Utilized to Identify Water Source from All Wells

and P-07s) did not observe any tracer at all. The South Domain is compartmentalized and isolated from the rest of the field. This understanding is further supported by the fact that no water injection supports in this domain. Regular water analyses of produced water from these wells showed clear formation water/aquifer water composition. Oil finger printing analyses of oil from these wells also indicated different oil compare to that from North and Central domains.

Other than tracer injection/monitoring, regular produced water chemical analyses were utilized to track water movement of injected sea-water and formation/aquifer water. Fig. 11 shows some example wells' produced water analysis results where source of water produced can be monitored and tracked regularly with appropriate surveillance plan. A water distribution map, as shown in Fig. 12, was derived from the results of both tracer and water chemical analysis interpretation. This water distribution map is used for Rang Dong Basement full field reservoir management strategy. 


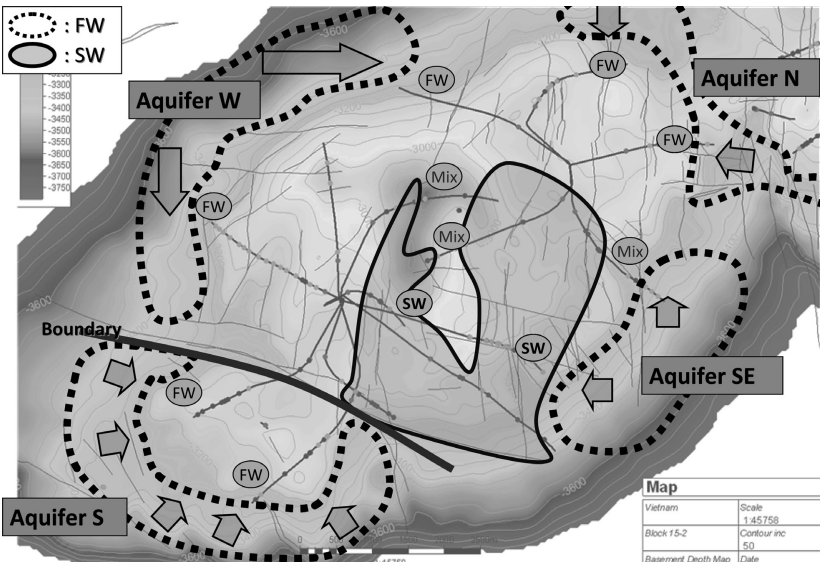

Fig. 12 Water Distribution Map for Center and South Domains

\section{Case Example}

2 case examples are detailed below to show how integrated results (i.e. tracer injection/monitoring analyses integrated with all available information) were used to derive at actual well planning or reservoir management strategy that was eventually applied in Rang Dong field.

\subsection{Case Example \#1 :}

Direct Flow Path from Injector to Producer (I-01s and P-01s)

Water injection from I-01s has very strong and direct flow path to producer P-01s (Fig. 13). This was evident in the tracer results which clearly showed high concentration of tracer breakthrough in just 36 days to reach P-01s. Seismic imaging using the Controlled Beam Migration (CBM) technique (Fig. 14) also showed at least 2 fracture lineaments interpreted to connect both I-01s and P-01s. This is consistent with tracer response curve (Fig. 8) showing at least 2 peaks in tracer concentration.

In addition, water chemical composition analysis of produced water from P-01s showed clearly the water was from injected water (sea water). Oxygen and Hydrogen Isotopes in the produced water were from sea water origin meaning injected water (Fig. 15).

$\mathrm{P}-01$ s produced water with rapid increasing water cut very

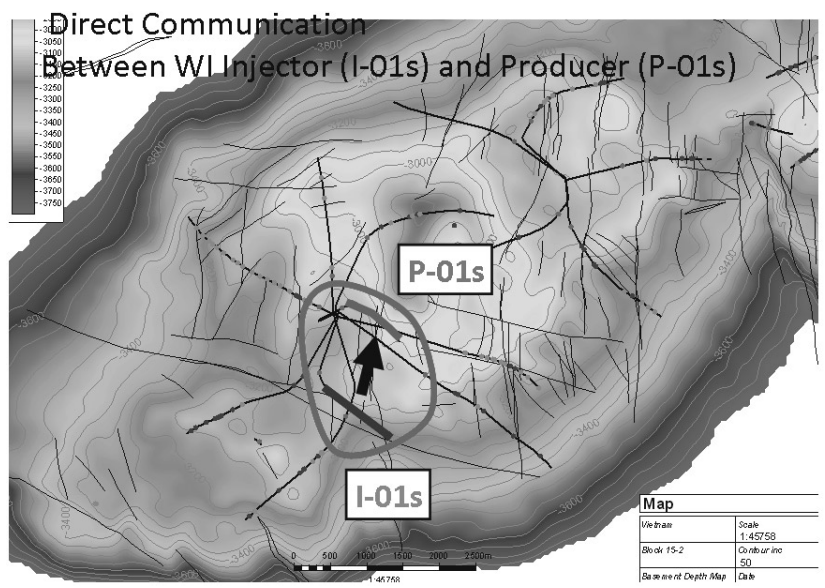

Fig. 13 Direct Communication between Water Injector I-01s and Producer P-01s

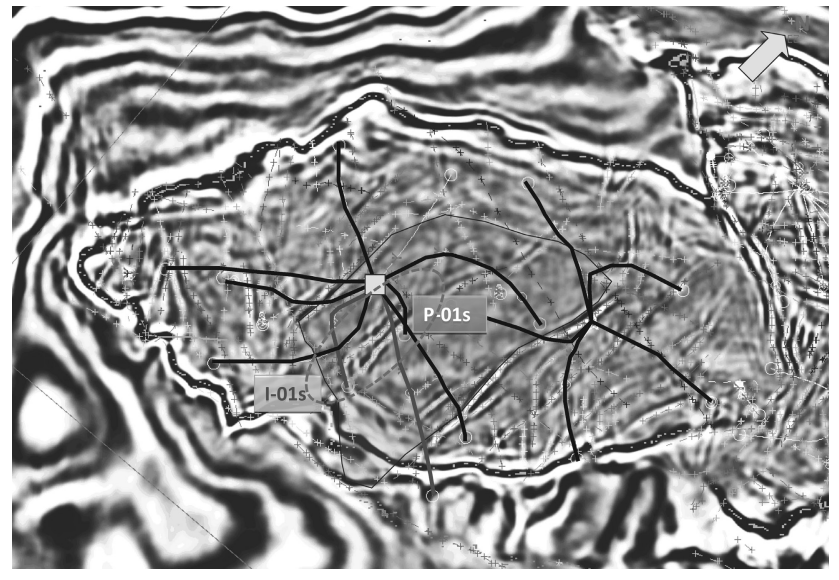

Fig. 14 CBM (Controlled Beam Migration) Depth Slide of I-01s and P-01s

shortly after started injection at I-01s. Due to strong direct communication of P-01s from I-01s, P-01s oil production was effected by high water production. P-01s rapidly watered out if continued to remain open continuously with injection from I-01s.

Therefore, a cyclic production scheme was applied for this pair of injector-producer. This strategy was used to allow oil-water to segregate in the fractures to continue to produce remaining unswept oil between I-01s and P-01s. This would otherwise be impossible to continue to inject and produce from this pair of well. Fig. 16 demonstrated that a stable oil production can be achieved from P-01s with this cyclic strategy.

\subsection{Case Example \#2 :}

No Water Injection Support Wells (Isolated Area)

There are two areas of Rang Dong Basement Reservoir that are compartmentalized. Those areas, as appeared in Fig. 17, are in the South Domain and the upper part of North Domain. The producers in those areas are isolated from the water injection support. No tracers were observed in all of those wells. Other supporting data also showed consistent results. Water chemical analysis results indicated that the water produced was formation/aquifer water. Oil finger printing analysis of oil produced showed compartmentalized oil from those regions with different signature oil from the rest of the field.

Reservoir pressure in these wells declined faster compared to other wells due to isolation. Aquifer strength in these areas is also relatively weak. Because of that, secondary gas cap was formed relatively early in the production stage. The strategy to mitigate against too rapid decline of energy was to control production at the choke for each well. This strategy targets to achieve even sweep using gravity by reducing fluid flow through fixed path in which gas or water may pre-maturely breakthrough. This is illustrated in the schematic in Fig. 18.

Fig. 19 and 20 showed 2 examples of the actual performance of the 2 wells in the isolated areas. Well \#1 and Well \#2 both showed stable GOR trend and stable BHP as a result of production control at the choke. And the outcome is optimized oil production at stable production rate. 


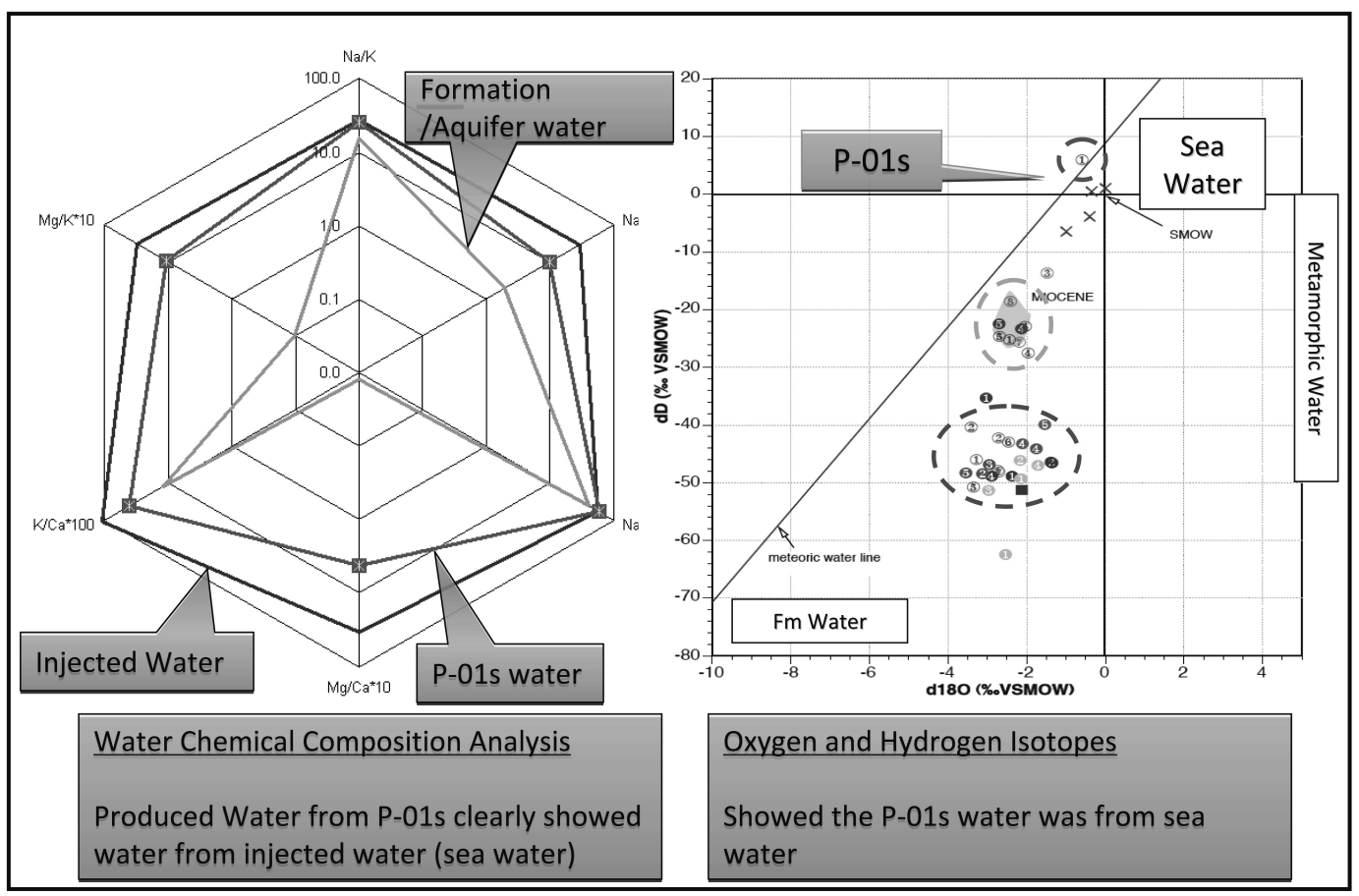

Fig. 15 Water Chemical Analysis and Oxygen/Hydrogen Isotopes Results of P-01s

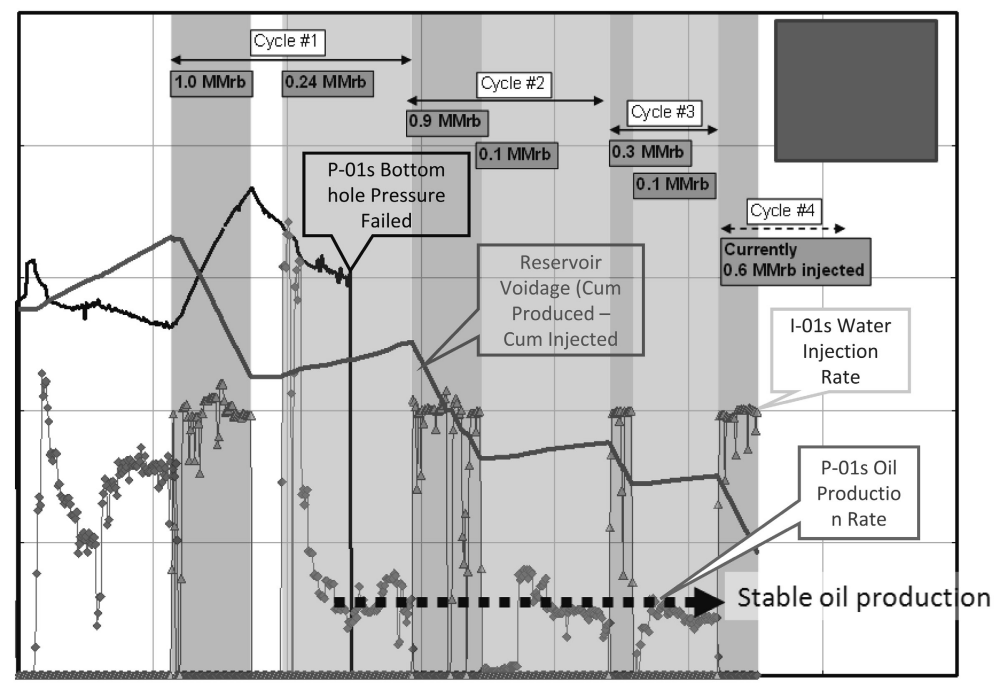

Fig. 16 Cyclic Injection and Production Strategy for WI I-01s and OP P-01s
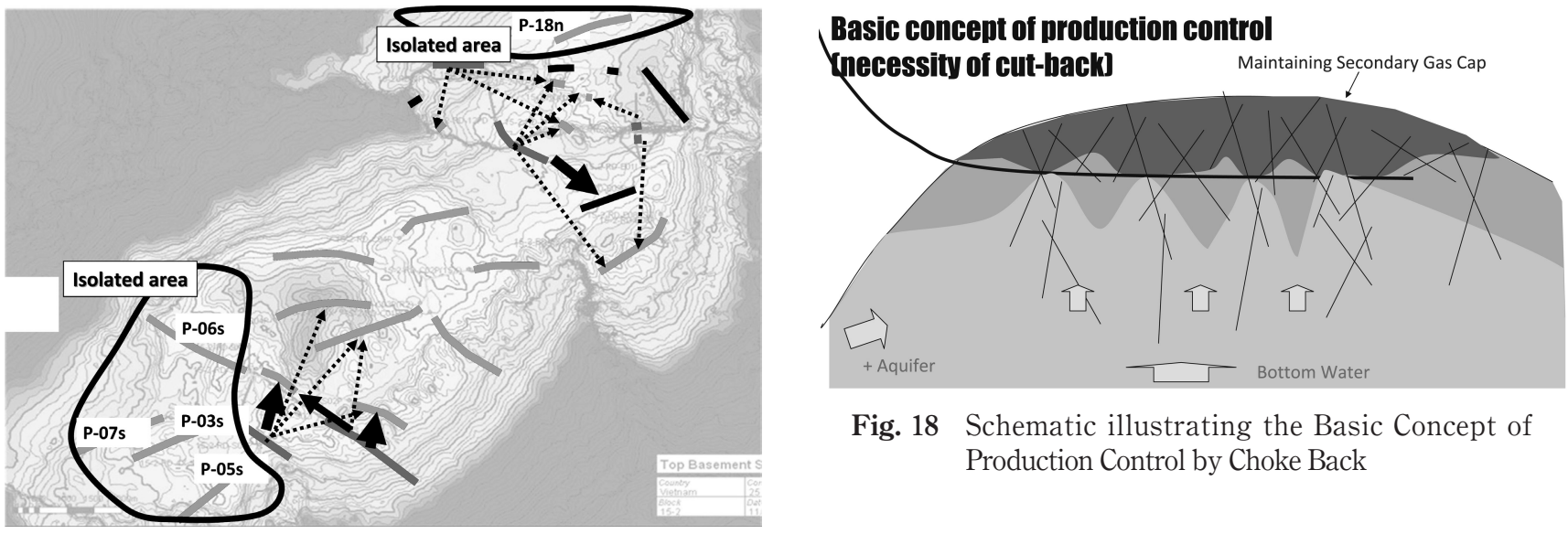

Fig. 18 Schematic illustrating the Basic Concept of Production Control by Choke Back

Fig. 17 Isolated Areas of Rang Dong Basement Reservoir 


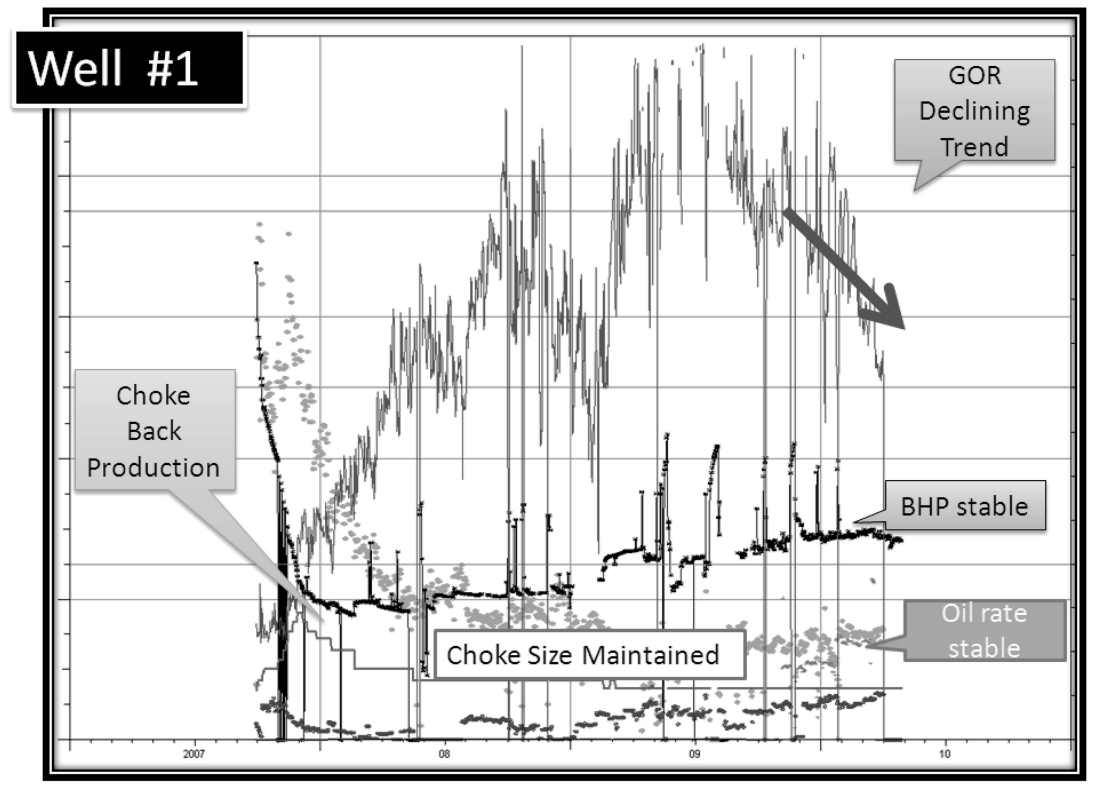

Fig. 19 Actual Performance of Well \#1 as a result of Production Control at the choke

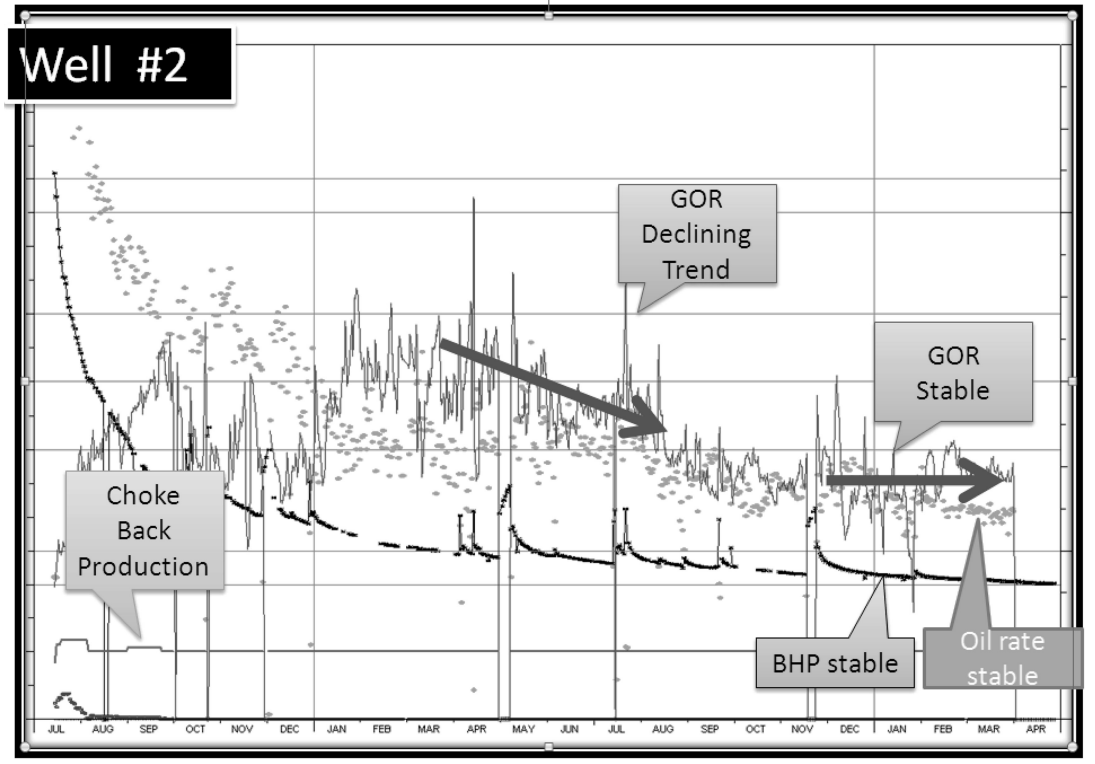

Fig. 20 Actual Performance of Well \#2 as a result of Production Control at the choke

\section{Conclusion}

In Rang Dong, radioactive tracer injection and monitoring has proved to be effective in obtaining valuable information on injector to producer fracture flow path in a basement reservoir. However, interpretation is not straightforward ; therefore integration with other data is important to get consistent and accurate interpretation. The integration approach with all available data was important to apply a prudent and effective reservoir management strategy at Rang Dong fractured basement reservoir.

\section{Forward Plan and Work in Progress}

We are currently working on Residence Time Distribution Modeling (RTD) to match to the actual tracer response curve for the wells. Essentially, the actual tracer response curve is a RTD of system in pulse injection mode. The establishment of a RTD model for each pair of injector and producer requires the matching of actual tracer curve with RTD model (s). This serves to validate the RTD model with actual data. Once we have the representative RTD model(s), we can use this model to estimate number of possible flooded conduits connecting the injector to the producer. The swept or flooded volume in each fracture can also be estimated using the method.

Residence time analyses were shown to be valid for some set of field condition, including fractured reservoirs, partial recovery of tracer, variable injection and production rates, etc by Shook et al. (Shook et al. ${ }^{6)}$ ) 


\section{Acknowledgement}

The authors wish to thank PetroVietnam (PVN), PetroVietnam Exploration Production Corporation (PVEP) and ConocoPhillips for granting permission to publish the results of this study.

\section{SI Metric conversion factors}

$$
\begin{aligned}
& \mathrm{bbl} \times 1.589874 \mathrm{E}-01=\mathrm{m}^{3} \\
& \mathrm{ft} \times 3.048^{*} \mathrm{E}-01=\mathrm{m} \\
& \mathrm{ft}^{3} \times 2.831685 \mathrm{E}-02=\mathrm{m}^{3} \\
& \mathrm{md} \times 9.86923 \mathrm{E}-16=\mathrm{m}^{2} \\
& \mathrm{psi} \times 6.894757 \mathrm{E}+03=\mathrm{Pa} \\
& \mathrm{cp} \times 1.0 * \mathrm{E}-03=\mathrm{Pa} \cdot \mathrm{sec} \\
& * \text { conversion factors are exact. }
\end{aligned}
$$

\section{References}

1) Nelson, R.A. ; Geological Analysis of Naturally Fractured Reservoirs, Gulf Professional Publishing, 2001.

2) Greenkorn, R.A. : Experimental Studies of Waterflood Tracer, J. Pet. Tech., January 1962, 87-92, Trans, AIME, 225.

3) Wagner, O.R. : The Use of Tracers in Diagnosing Interwell Reservoir Heterogeneities-Field Results, J. Pet. Tech., November 1997, 1410-1416.

4) Zemel, B. : Tracers in the Oil Field, Elsevier Science, 1995.

5) Shook, G.M., Ashley, S.L., and Wilie, A. : Tracer Testing Methods : Test design and Implementation, Tracer Selection and Interpretation Methods, INEEL report, January 2004.

6) Shook, G.M., Pope, G.A., and Asakawa, K. : Determining Reservoir properties and Flood Performance from Tracer Test Analysis, SPE 124614 paper presented at the SPE Annual Technical Conference and Exhibition, New Orleans, LA., 2009.
要 旨

ランドン基盤岩油田油層管理におけるトレー サ一圧入・監視情報とさまざまな観測情報を 利用した統合アプローチ

$$
\text { ウーイキアムチャイ・畠山 厚志 }
$$$$
\text { グエンチュチュエン }
$$

ランドン基盤岩油層は花崗岩質のフラクチャー型油層で ある。炭酸塩岩のフラクチャーシステムと異なり, 基盤岩 の岩体の孔隙は無視でき, 貯油と生産はフラクチャーシス テムに依存する。1 次回収後, 原油の追加回収のため水圧 入を開始した。

フラクチャーシステムでの水圧入は，フラクチャーの連 続性, 形状, 向きにより効果が異なるため, 非常に予測が 困難である。基盤岩油層の水圧入計画を管理するため，流 れの方向を注意深く理解することが重要である。そこで, 放射性のトレーサーの圧入・監視により流体経路に関する 情報を取得することとした。

トレーサーの圧入・監視技術が確立されたことにより, 坑井間の導通, 不均質性, 流体力学に関するデー夕が得ら れることが確認されが, データの解釈は単純ではない。こ のため, 精確で矛盾のない解釈を行うためには, 生産デー 夕などを含む周辺情報を統合して評価することが重要で ある。

本論文では，掘削計画・油層管理を目的として，トレー サ一圧入・監視と, 他の観測データの適用を統合的アプロー チの一例として紹介する。観測データの例として, 定期的 にサンプリングしている生産水の化学組成がある。この方 法により, 圧入水・地層水・帯水層水の移動, 確認が可能 である。

原油のフィンガープリントもまた, 解釈に供するデータ の一部として活用され，油層の区画化・延長，連続性など の評価が可能である。他に坑井の生産履歴, 坑井圧力解析 結果, 物質収支法などのデー夕も利用された。本論文では, 実際にフィールドで掘削計画・油層管理計画に用いられた, トレーサー圧入・監視データの解析と他の周辺データの統 合的活用について実例を示す。 